\title{
PEMBUATAN BIODIESEL DARI RBDPO DENGAN KATALIS CANGKANG KEPAH
}

\author{
M. Yusuf Ritonga, Anda Putra \\ Departemen Teknik Kimia, Fakultas Teknik, Universitas Sumatera Utara, \\ Jl. Almamater Kampus USU Medan 20155, Indonesia \\ Email : anda_shi@yahoo.com
}

\begin{abstract}
Abstrak
Biodiesel merupakan bahan bakar rendah emisi pengganti diesel yang terbuat dari sumber daya terbarukan dan limbah minyak. Tujuan dari penelitian ini adalah untuk mempelajari katalis $\mathrm{CaO}$ dalam pembuatan biodiesel dari RBDPO dengan katalis cangkang kepah melalui proses kalsinasi $\mathrm{CaCO}_{3}$ dengan suhu $900^{\circ} \mathrm{C}$ dan waktu 3,5 jam akan diperoleh kadar $\mathrm{CaO}$ sebesar 68,35\%. Pengaruh dari berbagai variabel proses seperti jenis katalis, waktu reaksi, jumlah katalis dan perbandingan mol Metanol / minyak diamati dalam percobaan ini. Spesifikasi biodiesel seperti kadar metil ester, densitas, viskositas, dan titik nyala dibandingkan dengan Standar Nasional Indonesia (SNI). Di bawah kondisi terbaik, yield maksimum, kemurnian, densitas, viskositas dan titik nyala dari biodiesel RBDPO berturut-turut sebesar $84,0179 \%, 97,98 \%, 875,47 \mathrm{~kg} / \mathrm{m}^{3}, 4,99 \mathrm{cSt}$ dan $122^{\circ} \mathrm{C}$ yang didapat dengan menggunakan perbandingan molar metanol : RBDPO 12:1 pada suhu $60^{\circ} \mathrm{C}$ dengan waktu reaksi 2 jam dengan adanya katalis $\mathrm{CaO} 5 \%$. Hasil yang diperoleh pada penelitian ini menunjukkan bahwa katalis heterogen $\mathrm{CaO}$ dari cangkang kepah cocok untuk dijadikan katalis dalam pembuatan biodiesel.
\end{abstract}

Kata kunci : biodiesel, RBDPO, cangkang kepah, transesterifikasi, katalis heterogen

\begin{abstract}
Biodiesel is a low-emission diesel fuel substitute made from renewable resources and waste oil. The objective of the study was to study of CaO catalysts in biodiesel production from RBDPO with clam shell catalyst through calcinations of $\mathrm{CaCO}_{3}$ with temperature of $900^{\circ} \mathrm{C}$ and 3.5 hours will be obtained $\mathrm{CaO}$ content of $68,35 \%$. Effect of various process variables such as type of catalyst, reaction time, amount of catalyst and molar ratio of Methanol / oil were investigated. The biodiesel properties like methyl ester content, density, viscosity, and flash point was compared with Indonesian Standard (SNI). Under the best condition, the maximum yield, purity, density, viscosity and flash point of biodiesel RBDPO respectively for $84,0179 \%, 97,98 \%, 875,47 \mathrm{~kg} / \mathrm{m}^{3}, 4,99 \mathrm{cSt}$ and $122^{\circ} \mathrm{C}$ was obtained by using 12:1 molar ratio of methanol to $R B D P O$ oil at $60^{\circ} \mathrm{C}$, for a reaction time of 2 hours in the presence $5 \mathrm{wt} \%$ of $\mathrm{CaO}$ catalyst. The results of this research showed that heterogeneous catalysts $\mathrm{CaO}$ derived from clam shell suitable to be used as catalysts in biodiesel production.
\end{abstract}

Key word : biodiesel, RBDPO, clam shell, transesterification, heterogeneous catalyst

\section{Pendahuluan}

Polusi udara adalah salah satu masalah lingkungan yang sangat serius di seluruh dunia. Karena mesin diesel dari bus dan truk menghasilkan sejumlah besar NOx dan partikulat, bahan bakar alternatif yang bersih sangat diperlukan [19]. Sebagai bahan bakar yang efektif, minyak bumi telah digunakan untuk memenuhi kebutuhannya dari konsumsi energi. Tapi ketergantungan manusia sepenuhnya pada bahan bakar fosil dapat menyebabkan defisit besar di masa depan [2]. Berdasarkan data dari Sekretariat Panitia Teknis Sumber Energi, (2006), distribusi penggunaan sumber energi nasional untuk Bahan Bakar Minyak (BBM) sebesar 60\%, gas 16\%, batubara $12 \%$, listrik $10 \%$ dan LPG $1 \%$ dari total 606,13 juta SBM (setara bahan bakar minyak), oleh karena itu penggunaan energi alternatif seperti biodiesel sangatlah diperlukan [29].Biodiesel telah menjadi salah satu alternatif yang paling menjanjikan di dunia [4]. Produksi biodiesel telah menerima banyak perhatian baru-baru ini sebagai zat yang bisa terurai secara biologis dan bahan bakar yang tidak membuat polusi. Bahan bakar ini mengurangi tingkat pemanasan global seperti $\mathrm{CO}_{2}$, $\mathrm{CO}$, dan $\mathrm{So}_{\mathrm{x}}$. Transportasi menjadi penyumbang utama gas rumah kaca, umumnya karbon dioksida $\left(\mathrm{CO}_{2}\right)$, metana $\left(\mathrm{CH}_{4}\right)$, nitrogen oksida $\left(\mathrm{No}_{\mathrm{x}}\right)$, ozon $\left(\mathrm{O}_{3}\right)$ dan lain-lain yang dikenal sebagai gas rumah kaca [22]. Bahan baku biodiesel yang berpotensi di Indonesia saat ini adalah minyak kelapa sawit dimana produksi kelapa sawit sangat tinggi di Indonesia [7]. Refined, Bleached and Deodorized Palm Oil (RBDPO) adalah minyak sawit yang telah mengalami proses penyulingan untuk menghilangkan asam lemak bebas serta penjernihan untuk menghilangkan warna dan penghilangan bau. Minyak ini dikenal khalayak 
ramai sebagai minyak goreng [32]. Indonesia telah menjadi produsen minyak sawit terbesar di dunia, melebihi Malaysia. Pada tahun 2007 luas lahan sawit mencapai 6,78 juta ha dengan produksi CPO mencapai 17,37 juta ton [8].

\section{Teori}

Minyak kelapa sawit mentah (CPO) dapat diolah menjadi minyak goreng (RBDPO). Dalam proses pengolahan tersebut zat-zat pengotor seperti air, mineral-mineral logam, zat-zat lendir dan asam lemak bebas perlu dihilangkan melalui proses pemurnian. RBDPO hasil pemurnian CPO umumnya dikembangkan sebagai dasar pembuatan metil ester turunan minyak kelapa sawit melalui reaksi transesterifikasi dan produk ini digunakan sebagai biodiesel [30].

Untuk menghindari operasi penyisihan katalis dan pembentukan sabun, banyak usaha telah dilakukan yaitu mencoba katalis asam padat atau katalis basa yang dapat digunakan menjadi katalis heterogen [14]. Katalis heterogen adalah kandidat yang menjanjikan untuk biodiesel produksi dari minyak nabati. Katalis heterogen biasanya juga murah [12]. Proses katalitik heterogen dapat mengatasi masalah katalis homogen karena katalis padat dapat dengan mudah dipulihkan dan juga dapat digunakan kembali. Selain itu, proses netralisasi yang menghasilkan sejumlah besar air akan dihilangkan [9]. Katalisis yang menggunakan katalis heterogen padat berjalan lebih lambat daripada katalis homogen, namun dapat diintegrasikan dengan teknologi pengolahan kontinu [21]. Katalis basa heterogen $\mathrm{CaO}$ dapat dibuat melalui proses kalsinasi $\mathrm{CaCO}_{3}$ [31]. Produksi biodiesel dengan proses transesterifikasi heterogen dapat dicapai oleh semua katalis $\mathrm{CaO}$ terutama cangkang kepah [10]. Kalsium oksida yang berasal dari cangkang kepah telah terbukti menjadi katalis yang aktif dalam produksi biodiesel [9]. Ditemukan bahwa katalis ini terdiri atas kalsium (97\%) dan beberapa zat-zat lain ( $\mathrm{Si}$, $\mathrm{Na}, \mathrm{Fe}, \mathrm{Al}, \mathrm{Sr}, \mathrm{S}, \mathrm{Mn}$ ) yang telah dianalisa oleh XRF (Nair, dkk., 2012). industri ini menjanjikan sumber daya katalis yang murah dan bisa menghasilkan biodiesel yang murah [10].

Transesterifikasi adalah proses yang menggunakan Metanol (misalnya metanol, etanol, propanol atau butanol), dengan adanya katalis untuk memecah molekul dari minyak mentah menjadi metil atau etil ester dari minyak tersebut dan gliserol sebagai produk sampingan secara proses kimia [6]. Minyak tidak boleh mengandung lebih dari 1\% FFA untuk reaksi transesterifikasi. Jika tingkat FFA melebihi jumlah ini, pembentukan sabun akan menghambat pemisahan ester dari gliserin dan juga mengurangi tingkat konversi ester [13].
Faktor-faktor yang mempengaruhi reaksi transesterifikasi katalis heterogen antara lain :

a. Molar rasio (minyak:Metanol)

Rasio stoikiometri untuk transesterifikasi memerlukan tiga mol Metanol dan satu mol trigliserida untuk menghasilkan tiga mol asam lemak metil ester dan satu mol gliserol. Namun, transesterifikasi merupakan reaksi kesetimbangan di mana rasio Molar tinggi digunakan untuk mendorong reaksi ke kanan, meningkatkan kelarutan dan kontak antara trigliserida dan molekul Metanol [22].

b. Pengadukan

Campuran yang bereaksi membentuk dua lapisan dengan minyak pada lapisan bawah dan katalis pada lapisan atas. Oleh karena itu pencampuran dua lapisan itu perlu dilakukan [25]. Tanpa pencampuran, reaksi hanya terjadi pada antarmuka antara dua lapisan dan dianggap terlalu lambat untuk menjadi layak [22].

c. Kandungan air

Produksi metal ester menurun dengan bertambahnya jumlah air dalam reaksi [1].

d. Katalis

untuk jumlah katalis yang tinggi, konversi tetap stabil dan hanya menambah biaya produksi [18].

e. Waktu Reaksi

Pada awalnya, reaksi lambat karena pencampuran dan penyebaran metanol dengan minyak dan kenaikan yield biodiesel sangat cepat dalam rentang waktu reaksi dari 0,5 sampai 1 jam. Seterusnya, waktu reaksi berlebihan akan berdampak berkurangnya hasil produksi biodiesel karena reaksi mundur [24].

f. Suhu Reaksi

Suhu minimum yang digunakan adalah $50^{\circ} \mathrm{C}$. Dibawah $50^{\circ} \mathrm{C}$, viskositas minyak yang tinggi menyebabkan masalah dalam pengadukan. Suhu penyimpanan untuk minyak sawit sekitar $55^{\circ} \mathrm{C}$ untuk menjaga likuiditas. Suhu maksimum adalah $65^{\circ} \mathrm{C}$ karena titik didih metanol adalah $68^{\circ} \mathrm{C}$ [5].

g. Kandungan asam lemak

Tingkat konversi metil ester turun di bawah $90 \%$ untuk kadar asam lemak bebas di atas $5 \% .5 \%$ FFA akan menghasilkan campuran sabun padat yang mencegah pemisahan antara gliserin dari metil ester [3].

\section{Metodologi Penelitian \\ Bahan Baku dan Preparasi Katalis}

RBDPO dibeli dari pajak Sukaramai Medan, Indonesia. Komposisi asam lemak dalam RBDPO diberikan dalam Tabel 1. Cangkang kepah dikumpulkan dari pajak Sukaramai Medan, Indonesia. Cangkang kepah ini diubah menjadi abu 
cangkang kepah dimana digunakan sebagai katalis dengan zat $\mathrm{CaO}$ aktif dan dikalsinasi pada suhu $900^{\circ} \mathrm{C}$ dan waktu 3,5 jam dalam muffle furnace [27]. Hasil kalsinasi cangkang kepah dianalisis dengan menggunakan AAS (Atomic Absorption Spectrophotometry). Karakteristik dari abu cangkang kepah diberikan dalam Tabel 2. Abu cangkang kepah tersebut disimpan dalam tempat tertutup untuk menghindari reaksi dengan $\mathrm{CO}_{2}$ dan menjaga kelembaban dari abu. Semua bahan kimia lain yang digunakan adalah reagen pro analis.

Tabel 1. Komposisi Asam Lemak dari RBDPO

\begin{tabular}{|l|r|}
\hline \multicolumn{1}{|c|}{ Asam lemak } & Komposisi (b/b\%) \\
\hline Laurat (C12:0) & 0,4 \\
\hline Miristat (C14:0) & 0,7 \\
\hline Palmitat (C16:0) & 34,7 \\
\hline Palmitoleiat (C16:1) & 0,1 \\
\hline Stearat (C18:0) & 3,8 \\
\hline Oleat (C18:1) & 41,0 \\
\hline Linoleat (C18:2) & 18,2 \\
\hline Linolenat (C18:3) & 0,7 \\
\hline Arakidat (C20:0) & 0,3 \\
\hline Eikosenoat (C20:1) & 0,2 \\
\hline
\end{tabular}

Tabel 2. Karakteristik dari Abu Cangkang Kepah

\begin{tabular}{|l|c|r|}
\hline Parameter & Hasil Uji & $\begin{array}{l}\text { Metode } \\
\text { Analisis }\end{array}$ \\
\hline $\mathrm{CaO}$ & $68,35 \%$ & AAS \\
\hline Kadar air & $0,12 \%$ & Oven \\
\hline $\mathrm{pH}$ & 12,3 & $\mathrm{pH}$ meter \\
\hline
\end{tabular}

\section{Reaksi Transesterifikasi}

Reaksi transesterifikasi dilakukan dalam reaktor batch. Minyak hasil esterifikasi yang berada dalam labu $1000 \mathrm{~cm}^{3}$ dan dilengkapi dengan refluks kondensor diaduk pada suhu $60^{\circ} \mathrm{C}$. Campuran metanol dan katalis $\mathrm{CaO}$ ditambahkan ke dalam minyak. Kemudian reaksi transesterifikasi dilakukan dalam berbagai kondisi perbandigan mol minyak:Metanol (1:6, 1:9, dan 1:12), Waktu reaksi $(90,120,150$ menit) dan jumlah abu cangkang kepah (4, 5, dan 6 b/b\%). Suhu reaksi adalah $60^{\circ} \mathrm{C}$ dan campuran reaksi diaduk dengan pengaduk mekanis pada $600 \mathrm{rpm}$. Setelah reaksi selesai, campuran reaksi dituang ke dalam corong pemisah. Campuran reaksi dibiarkan dingin dan terjadi pemisahan dari tiga lapisan. Lapisan atas terdiri dari metanol yang tidak bereaksi, metil ester, dan trigliserida yang tidak bereaksi, lapisan tengah terdiri dari gliserol, dan lapisan bawah terdiri dari campuran $\mathrm{CaO}$ padat dan sejumlah kecil gliserol. Setelah pemisahan dari tiga lapisan dengan sedimentasi, lapisan atas dicuci dengan air tiga kali. Tahap pencucian berfungsi untuk menghilangkan sisa metanol. Kemudian metil ester yang telah dicuci dipanaskan pada suhu $105^{\circ} \mathrm{C}$ selama 10 menit untuk menghilangkan sisa air. Produk sebelum dan sesudah pengeringan ditimbang untuk menghitung yield metil ester dengan membagi berat akhir metil ester dengan berat awal minyak.

\section{Analisis Fatty Acid Methyl Ester (FAME)}

Komposisi dari masing-masing metil ester ditentukan menggunakan kromatografer gas yang dilengkapi dengan detektor ionisasi api dan injector auto.

\section{Analisis Lainnya}

Densitas, viskositas kinematik, dan titik nyala dari masing-masing metil ester dievaluasi dan dibandingkan dengan standar SNI [17].

\section{Hasil dan Pembahasan \\ Preparasi Abu Cangkang Kepah}

Sampel katalis cangkang kepah yang dikalsinasi pada suhu $900^{\circ} \mathrm{C}$ adalah katalis yang paling aktif. Berdasarkan penelitian yang dilakukan oleh Nair, dkk., [27], kondisi optimum proses kalsinasi $\mathrm{CaO}$ dari cangkang kepah diperoleh pada suhu $900^{\circ} \mathrm{C}$ dan waktu 3,5 jam.

Yield sebesar 84,0179\% diperoleh dengan adanya katalis abu cangkang kepah yang dikalsinasi pada suhu $900^{\circ} \mathrm{C}$ selama 3,5 jam. Perlakuan tersebut ditetapkan dikarenakan menurut teori Endalew, dkk 2011 bahwa perlakuan yang tidak sama pada cangkang kepah seperti suhu kalsinasi yang lebih tinggi dan waktu yang lebih lama mengurangi luas permukaan dan meningkatkan diameter pori [12]. Berikut merupakan unsur yang terdapat dalam cangkang kepah [9].

Tabel 3. Analisis Enegy Dispersive X-Ray Fluorescence Spectroscopy (EDXRF) dari cangkang kepah

\begin{tabular}{|c|c|c|c|c|c|}
\hline Katalis & Ca & Si & $\mathbf{S}$ & $\mathbf{S r}$ & $\begin{array}{c}\text { Lain- } \\
\text { lain }\end{array}$ \\
\hline $\begin{array}{c}\text { Cangkang } \\
\text { Kepah }\end{array}$ & 98,6 & 0,6 & 0,3 & 0,3 & 0,1 \\
\hline
\end{tabular}

\section{Reaksi Transesterifikasi}

Dengan transesterifikasi dalam proses heterogen, RBDPO dicampur dengan metanol dan dikatalisis oleh abu cangkang kepah. Trigliserida akan terkonversi menjadi di- dan mono-gliserida, dan selanjutnya membentuk biodiesel (metil ester) dan gliserol. Tabel 4 merangkum kondisi percobaan transesterifikasi dari RBDPO dengan metanol dengan adanya katalis abu cangkang kepah dan $\mathrm{CaO}$ murni dan perhitungan yield 
sedangkan tabel 5 meninjau katalis abu cangkang kepah saja dan perhitungan yield.

Tabel 4. Rasio Mol Metanol/Minyak (12:1), Suhu Reaksi $\left(60^{\circ} \mathrm{C}\right)$ dan Jumlah Katalis (5\%)

\begin{tabular}{|c|c|c|}
\hline $\begin{array}{c}\text { Waktu } \\
\text { Reaksi }\end{array}$ & Jenis Katalis & $\begin{array}{c}\text { Yield } \\
(\mathbf{b} / \mathbf{b} \%)\end{array}$ \\
\hline 90 & Abu Cangkang Kepah & 56,0014 \\
\hline 120 & Abu Cangkang Kepah & 84,0179 \\
\hline 150 & Abu Cangkang Kepah & 74,8079 \\
\hline 90 & CaO Murni & 49,8240 \\
\hline 120 & $\mathrm{CaO}$ Murni & 80,4225 \\
\hline 150 & $\mathrm{CaO}$ Murni & 66,4337 \\
\hline
\end{tabular}

Pengaruh Waktu Reaksi dan Jenis Katalis CaO

Hasil penelitian menggunakan variasi katalis $\mathrm{CaO}$ dan waktu reaksi dengan rasio mol alkohol/minyak $12: 1$, suhu reaksi $60^{\circ} \mathrm{C}$ dan jumlah katalis $6 \mathrm{~b} / \mathrm{b} \%$ dapat dilihat pada gambar 1 . Gambar 1 menunjukkan hubungan antara waktu reaksi terhadap yield metal ester dengan variasi jenis katalis $\mathrm{CaO}$. Dari grafik dapat dilihat katalis $\mathrm{CaO}$ dari abu cangkang kepah menghasilkan yield yang lebih tinggi daripada katalis $\mathrm{CaO}$ murni dan waktu reaksi yang optimum adalah 120 menit.

Untuk meningkatkan kekuatan dari satu oksida logam, campuran oksida logam yang lain dicampurkan [16]. Meskipun penggunaan katalis $\mathrm{CaO}$ yang sama banyak, tetapi katalis $\mathrm{CaO}$ dari abu cangkang kepah mempunyai logam minor seperti ( $\mathrm{Si}, \mathrm{Na}, \mathrm{Fe}, \mathrm{Al}, \mathrm{Sr}, \mathrm{S}, \mathrm{Mn}$ ) dimana bisa membantu meningkatkan yield dari biodiesel.

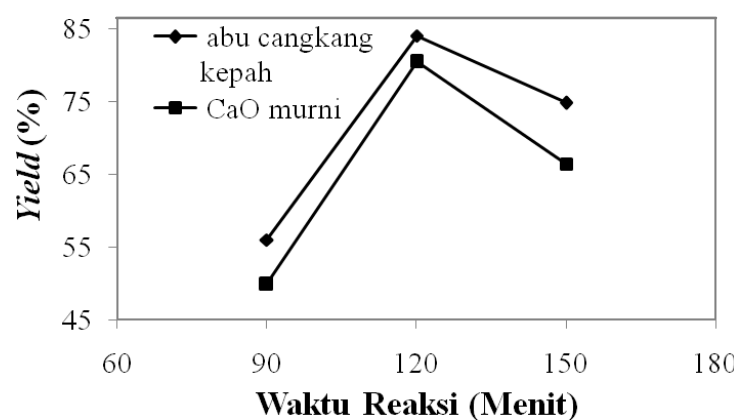

Gambar 1. Hubungan Antara Waktu Reaksi terhadap Yield pada Perbandingan Mol Metanol/Minyak 12:1 dan Suhu Reaksi $60^{\circ} \mathrm{C}$

Konversi meningkat seiring waktu reaksi di awal, reaksi lambat karena penyebaran alkohol ke minyak. Setelah beberapa saat, reaksi sangat cepat. Waktu reaksi berlebih akan menyebabkan penurunan yield karena reaksi bolak balik dari transesterifikasi [11]. Jenis katalis $\mathrm{CaO}$ terbaik adalah abu cangkang kepah dan waktu reaksi yang optimum adalah 2 jam. Hal ini sesuai dengan yang dilaporkan oleh Kawashima dkk [16] dan Encinar dkk [11].
Tabel 5. Waktu Reaksi (120 menit) dan Suhu Reaksi $\left(60^{\circ} \mathrm{C}\right)$

\begin{tabular}{|c|c|c|}
\hline $\begin{array}{c}\text { Rasi Mol } \\
\text { Metanol / } \\
\text { Minyak }\end{array}$ & $\begin{array}{c}\text { Jumlah katalis } \\
(\mathbf{b} / \mathbf{b} \%)\end{array}$ & $\begin{array}{c}\text { Yield } \\
(\mathbf{b} / \mathbf{b} \%)\end{array}$ \\
\hline $6: 1$ & 4 & 22,1937 \\
\hline $6: 1$ & 5 & 72,5009 \\
\hline $6: 1$ & 6 & 31,9793 \\
\hline $9: 1$ & 4 & 39,7135 \\
\hline $9: 1$ & 5 & 74,6417 \\
\hline $9: 1$ & 6 & 72,5633 \\
\hline $12: 1$ & 4 & 54,7072 \\
\hline $12: 1$ & 5 & 84,0179 \\
\hline $12: 1$ & 6 & 73,2663 \\
\hline
\end{tabular}

\section{Pengaruh Rasio Mol Metanol/Minyak}

Penelitian dilakukan pada variasi rasio mol Metanol/minyak dengan variasi jumlah katalis $\mathrm{CaO}$ dari 4, 5, 6 b/b\% dari minyak dan suhu reaksi $60^{\circ} \mathrm{C}$ dalam reaksi selama 2 jam. Gambar 2 menunjukkan hubungan antara rasio mol alkohol/minyak terhadap yield metil ester dengan variasi jumlah katalis abu cangkang kepah. Dari grafik dilihat bahwa semakin besar rasio metanol/minyak yang digunakan maka yield yang dihasilkan akan semakin besar.

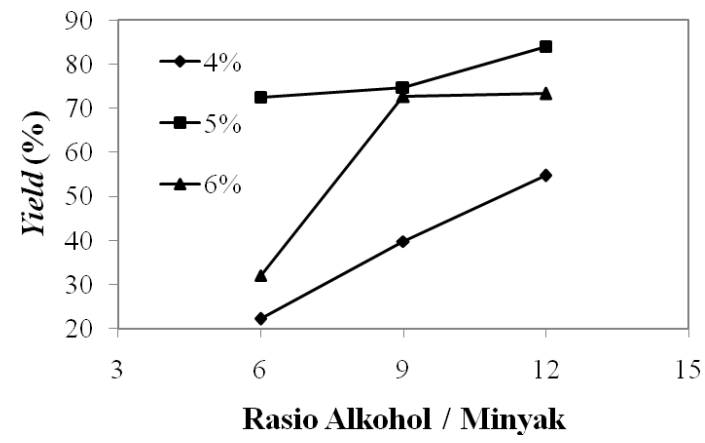

Gambar 2. Hubungan Antara Rasio Mol Metanol/Minyak terhadap Yield pada Waktu Reaksi 2 jam dan Suhu Reaksi $60^{\circ} \mathrm{C}$

Yield biodiesel dapat ditingkatkan dengan memggunakan lebih banyak metanol untuk menggeser kesetimbangan ke sisi kanan. Yield metil ester akan bertambah seiring dengan peningkatan rasio mol metanol terhadap minyak dari 6:1 ke 12:1 [11]. Perbandingan rasio mol metanol/minyak terbaik adalah pada 12:1 dengan jumlah katalis $\mathrm{CaO} 5$ b/b\% dari minyak. Hal ini sesuai dengan hasil yang dilaporkan oleh Encinar dkk [11].

\section{Pengaruh Jumlah Katalis}

Penelitian dilakukan pada variasi rasio mol metanol/minyak dengan variasi jumlah katalis $\mathrm{CaO}$ dari $4,5,6 \mathrm{~b} / \mathrm{b} \%$ dari minyak dan suhu reaksi $60^{\circ} \mathrm{C}$. Gambar 3 menunjukkan hubungan antara jumlah katalis abu cangkang kepah terhadap yield metil ester dengan perbandingan mol metanol/minyak. 
Dari grafik dapat dilihat bahwa pengingkatan jumlah katalis bisa meningkatkan yield, tetapi terlalu banyak katalis yang direaksikan maka yield akan menurun akibat dari campuran hasil transesterifikasi menjadi sangat kental.

Peningkatan jumlah katalis tidak menjamin peningkatan dari hasil produksi karena cairan menjadi sangat kental di beberapa titik sehingga mengalami penurunan dalam hal efisiensi reaksi. [23]. Terdapat jumlah katalis yang optimum cukup untuk mencapai hasil yang tinggi dari biodiesel [26]. Biasanya, ketika kita meningkatkan jumlah katalis, itu akan membantu untuk mempercepat reaksi dan memberikan hasil yang lebih baik. Setiap Reaksi melewati nilai katalis optimum akan mengurangi yield dari biodiesel [15]. Jumlah katalis $\mathrm{CaO}$ terbaik adalah $5 \mathrm{~b} / \mathrm{b} \%$ dari minyak dengan perbandingan metanol/minyak 12:1. Hal ini sesuai dengan yang dilaporkan oleh Lee dkk [23], Najem [26], Hossain dan Mazen [15].

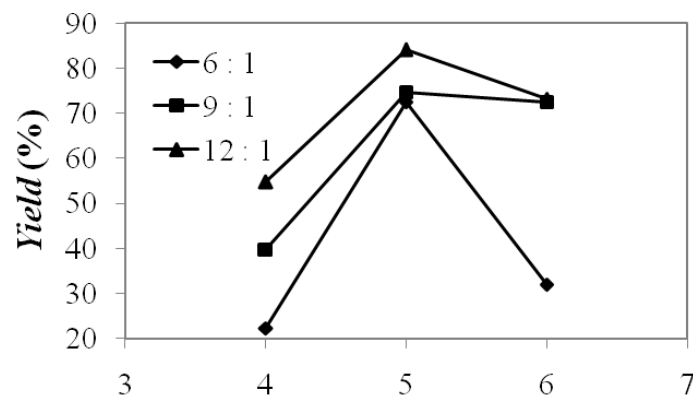

Katalis Abu Cangkang Kepah (\%)

Gambar 3. Hubungan Antara Jumlah Katalis Abu Cangkang Kepah terhadap Yield pada Waktu Reaksi 2 jam dan Suhu Reaksi $60^{\circ} \mathrm{C}$

\section{Sifat-Sifat Biodiesel dari RBDPO}

Sifat-sifat biodiesel dari RBDPO seperti densitas, viskositas kinematik, kemurnian, dan titik nyala dievaluasi dan dibandingkan dengan standar SNI. Tabel 6 menunjukkan beberapa sifat biodiesel yang diperoleh pada kondisi terbaik dari penelitian ini.

Tabel 6. Perbandingan Sifat-Sifat Biodiesel dari RBDPO Kondisi Terbaik dengan Biodiesel Standar SNI

\begin{tabular}{|l|r|r|}
\hline \multicolumn{1}{|c|}{ Sifat } & $\begin{array}{c}\text { Biodiesel } \\
\text { standar SNI }\end{array}$ & \multicolumn{1}{c|}{$\begin{array}{c}\text { Biodiesel } \\
\text { RBDPO }\end{array}$} \\
\hline $\begin{array}{l}\text { Densitas pada } \\
40^{\circ} \mathrm{C}\left(\mathrm{kg} / \mathrm{m}^{3}\right)\end{array}$ & $850-890$ & 875,47 \\
\hline $\begin{array}{l}\text { Viskositas } \\
\text { kinematik pada } \\
40^{\circ} \mathrm{C}\left(\mathrm{mm}^{2} / \mathrm{s}\right)\end{array}$ & $2,3-6,0$ & 4,99 \\
\hline Kemurnian $(\%)$ & $\begin{array}{r}\text { minimum } \\
96,5\end{array}$ & 97,98 \\
\hline Titik nyala $\left({ }^{\circ} \mathrm{C}\right)$ & $\begin{array}{r}\text { minimum } \\
100\end{array}$ & 122 \\
\hline
\end{tabular}

Pada kondisi terbaik tersebut, yield maksimum sebesar 84,0179\% diperoleh menggunakan perbandingan mol metanol/minyak adalah $12: 1$ pada suhu $60^{\circ} \mathrm{C}$ selama 2 jam dengan $5 \mathrm{~b} / \mathrm{b} \%$ katalis abu cangkang kepah.

\section{Densitas}

Batas densitas tercantum dalam SNI (850-890 $\mathrm{kg} / \mathrm{m}^{3}$ pada suhu $40^{\circ} \mathrm{C}$ ) [17]. Densitas biodiesel dari kondisi terbaik adalah $875,47 \mathrm{~kg} / \mathrm{m}^{3}$. Densitas biodiesel berada dalam rentang sifat biodiesel SNI. Gambar 4 menunjukkan hubungan antara jumlah katalis abu cangkang kepah terhadap densitas metil ester dengan suhu reaksi yang berbeda.

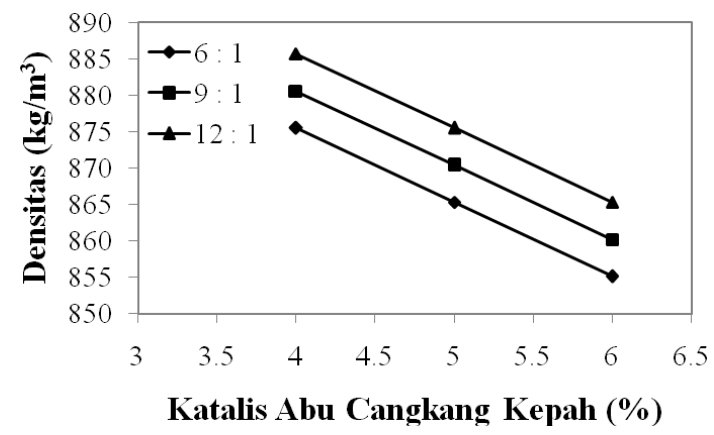

Gambar 4. Hubungan Antara Jumlah Katalis Abu Cangkang Kepah terhadap Densitas pada Waktu Reaksi 2 jam dan Suhu Reaksi $60^{\circ} \mathrm{C}$

\section{Viskositas Kinematik}

Viskositas adalah tingkat resistensi bahan untuk mengalir, bahan kental tinggi mengalir dengan susah payah, sementara yang kurang kental mengalir dengan mudah [28]. Semakin tinggi viskositas, semakin besar kecenderungan bahan bakar untuk menimbulkan penumpukan minyak di mesin sedangkan viskositas yang rendah tidak memberikan pelumasan yang cukup untuk pompa injeksi bahan bakar [20]. Gambar 5 menunjukkan hubungan antara jumlah katalis terhadap viskositas kinematik metil ester dengan perbandingan mol alkohol/minyak yang berbeda.

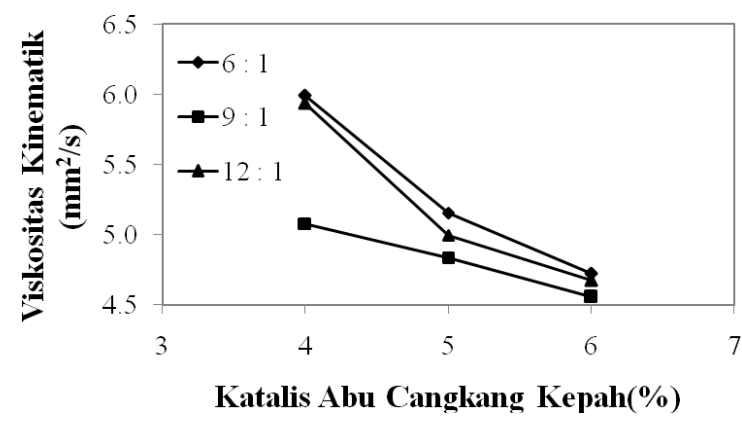

Gambar 5. Hubungan Antara Jumlah Katalis terhadap Viskositas Kinematik pada Waktu Reaksi 2 jam dan Suhu Reaksi $60^{\circ} \mathrm{C}$

Batas viskositas kinematik tercantum dalam SNI $\left(2,3-6,0 \mathrm{~mm}^{2} / \mathrm{s}\right.$ pada suhu $\left.40^{\circ} \mathrm{C}\right)$ [17]. 
Viskositas kinematik biodiesel dari kondisi terbaik adalah $4,99 \mathrm{~kg} / \mathrm{m}^{3}$. Viskositas kinematik biodiesel berada dalam lingkup rentang sifat biodiesel SNI.

\section{Titik Nyala \\ Sifat ini sebagai indikasi tindakan pencegahan yang harus diambil selama penanganan, transportasi, dan penyimpanan bahan bakar. Berkenaan dengan biodiesel, sifat titik nyala memiliki tujuan untuk membatasi jumlah metanol dalam biodiesel. Batas titik nyala tercantum dalam SNI (minimum $100^{\circ} \mathrm{C}$ ) [17]. Titik nyala biodiesel dari kondisi terbaik adalah $122^{\circ} \mathrm{C}$. Titik nyala biodiesel berada dalam lingkup rentang sifat biodiesel SNI.}

\section{Kesimpulan}

Dari hasil penelitian, kondisi terbaik untuk Metanolisis dari RBDPO adalah 5 b/b\% katalis abu cangkang kepah dari minyak, perbandingan mol metanol / minyak adalah 12:1, suhu reaksi $60^{\circ} \mathrm{C}$ selama 2 jam. Yield metil ester yang diperoleh adalah 84,0179\%. Sifat-sifat biodiesel seperti kandungan metil ester, densitas, viskositas kinematik, dan titik nyala dievaluasi dan berada dalam lingkup rentang sifat biodiesel SNI. Hasil penelitian ini menunjukkan bahwa penggunaan RBDPO sangat cocok sebagai bahan baku dan kalsium oksida dari cangkang kepah juga sangat cocok sebagai katalis berbiaya murah dan aktivitas yang tinggi untuk memproduksi biodiesel.

\section{Daftar Pustaka}

[1] Arun, Naveenji, Muthukumaran Sampath, S. Siddharth, Prasaanth R.A., "Studies of Base Catalyzed Transesterification of Karanja Oil", International Journal of Energy and Environment, Vol. 2 (2), hal. 351-356, 2011.

[2] Atadashi, I.M, M.K. Aroua dan A. Abdul Aziz, "High quality biodiesel and its diesel engine application", Journal, Renewable and Sustainable Energy Reviews, Vol.14 (7), hal. 1999-2008, 2010.

[3] Canakci, M. dan J. Van Gerpen, "Biodiesel Production Via Acid Catalysis", Journal, American Society of Agricultural Engineers, Vol. 42 (5), hal. 1203-1210, 1999.

[4] Chand. N., "Plant oils. Fuel of the future, J. Sci. Ind. Res. 61", Journal, hal. 7-16, 2002.

[5] Darnoko, D. dan Munir Cheryan, "Kinetics of Palm Oil Transesterification in a Batch Reactor”, Journal, JAOCS, Vol. 77, No. 12, hal. 1263-1268, 2000.

[6] Demirbas, Ayhan, "Biodiesel Production from Vegetable Oils Via Catalytic and NonCatalytic Supercritical Methanol Transesterification Methods", Journal,
Progress in Energy and Combustion Science, Vol. 31, hal. 466-487, 2005.

[7] Destianna, Mescha, Agustinus Zandy, Nazef dan Soraya Puspasari, "Intensifikasi Proses Produksi Biodiesel”, Karya Ilmiah, Institut Teknologi Bandung, 2007.

[8] Direktorat Jenderal Industri Agro Dan Kimia, "Roadmap Industri Pengolahan CPO", Departemen Perindustrian Jakarta, 2009.

[9] Empikul, N. Viriya, P. Krasae, B. Puttasawat, B. Yoosuk, N. Chollacoop dan K. Faungnawakij, "Waste shells of mollusk and egg as biodiesel production catalysts", Journal, Bioresource Technology, Vol. 101, hal. 3765-3767, 2009.

[10] Empikul, N. Viriya, P. Krasae, W. Nualpaeng, B. Yoosuk dan K. Faungnawakij, "Biodiesel production over Ca-based solid catalysts derived from industrial wastes", Journal, Fuel, Vol. 92, hal. 239-244, 2011.

[11] Encinar, J.M., J.F. Gonzales, G. Martinez dan A. Pardal, "Transesterification of Vegetables Oil In Subcritical Methanol Conditions", $18^{\text {th }}$ European Biomass Conference and Exhibition, 2010.

[12] Endalew, Abebe K., Yohannes Kiros dan Rolanda Zanzi. 2011, "Heterogeneous Catalysis for Biodiesel Production from Jatropha Curcas Oil (JCO)", Journal, Energy, hal. 1-8, 2011.

[13] Freedman, B., dan E. H. Pryde, "Fatty esters from vegetable oils for use as a diesel fuel", Journal, In Vegetable Oils Fuels: Proc. of the Intl, Conf. on Plant and Vegetable Oils as Fuels, hal : 117-122, St. Joseph, Mich : ASAE, 1982.

[14] Hillion, Gerard, Bruno Delfort, Dominique le Pennec, Laurent Bournay, Jean-Alain Chodorge, "Biodiesel Production By a Continuous Process Using a Heterogeneous Catalyst”, Journal, Fuel Chem, Vol. 48 (2), hal. 637, 2003.

[15] Hossain, A.B.M.S. dan M.A. Mazen, "Effects of Catalyst Types and Concentrations on Biodiesel Production From Waste Soybean Oil Biomass as Renewable Energy and Environmental Recycling Process", Journal, Australian Journal of Crop Science, hal. 550-555, 2010.

[16] Kawashima, A., K. Matsubara, K. Honda, "Development of Heterogeneous Base Catalysts for Biodiesel Production. Bioresource Technology”, Journal, Vol. 99, hal. 3439-3443, 2008.

[17] Keputusan Direktur Jenderal, "Standar dan Mutu (Spesifikasi) Bahan Bakar Nabati (Biofuel) Jenis Biodiesel Sebagai Bahan 
Bakar Lain yang dipasarkan di Dalam Negeri", Kementerian Energi dan Sumber Daya Mineral Republik Indonesia Direktorat Jenderal Energi Baru, Terbarukan dan Konservasi Energi, No. 723 K/10/DJE/2013, 2013.

[18] Kiakalaieh, A. Talebian, N.A.S. Amin, A. Zarei dan H. Jaliliannosrati, "Biodiesel Production from High Free Fatty Acid Waste Cooking Oil by Solid Acid Catalyst", Proceedings of the $6^{\text {th }}$ International Conference on Process Systems Engineering (PSE ASIA), 2013.

[19] Kim, Hak-Joo, Bo-Seung Kang, Min-Ju Kim, Young Moo park, Deog-Keun Kim, Jin-Sek Lee dan Kwan-Young Lee, "Transesterification of Vegetable Oil to Biodiesel Using Heterogeneous Base Catalyst", Journal, Catalysis Today, hal. 315-320, 2004.

[20] Knothe, Gerhard, "Dependence of Biodiesel Fuel Properties on the Structure of Fatty Acid Alkyl Esters", Journal Fuel Processing Technology, Vol. 85, hal. 1059-1070, 2005.

[21] Kolesarova, Nina, Miroslav Hutnan, Viera Spalkova dan Michal Lazor, "Biodiesel ByProducts as Potential Substrates for Biogas Production", Proceedings, 37th International Conference of SSCHE, 2010.

[22] Kumar, Ved dan Padam Kant, "Biodiesel: Beneficial For Environment and Human Health", Journal, 2013.

[23] Lee, Dae-Won., Park, Young-Moo dan Lee, Kwan-Young, "Heterogeneous Base Catalysts for Transesterification in Biodiesel Synthesis", Journal, Catal Surv Asia, Vol.13, hal : 63-77, 2009.

[24] Liu, Kang dan Rui Wang, "Biodiesel Production by Transesterification of Duck Oil With Methanol in The Presence of Alkali Catalyst", Journal, Petroleum \& Coal, Vol. 55 (1), hal. 68-72, 2013.

[25] May, Choo Yuen, Yung Chee Liang, Cheng Sit Foon, Ma Ah Ngan, Chuah Cheng Hook dan Yusof Basiron, "Key Fuel Properties of Palm Oil Alkyl Esters", Journal, Fuel, Vol. 84, hal. 1717-1720, 2005.

[26] Najem, Samir Aldeen Khurshid, "Biodiesel Production by Using Heterogeneous Catalyst", Thesis, 2014.

[27] Nair, Praful, B. Singh, S.N. Upadhyay dan Y.C. Sharma, "Synthesis of biodiesel from low FFA waste frying oil using calcium oxide derived from Mereterix mereterix as a heterogeneous catalyst", Journal of Cleaner Production, Vol. 29-30, hal. 82-90, 2012.

[28] Okoro, Linus N., Fadila I. Sambo, Mukhtar Lawal dan Cliffor Nwaeburu, "Thermodynamic and Viscometric
Evaluation of Biodiesel and Blends from Olive Oil and Cashew Nut Oil", Research Journal of Chemical Sciences, Vol. 1 (4), hal. 90-97, 2011.

[29] Padil, Slamet Wahyuningsih dan Amir Awaluddin, "Pembuatan Biodiesel dari Minyak Kelapa melalui Reaksi Metanolisis Menggunakan Katalis $\mathrm{CaCO}_{3}$ yang dipijarkan", Jurnal, 2010.

[30] Sebayang, "Pemanfaatan Minyak Sereh Sebagai Zat Aditif Pada Blending Bahan Bakar Solar Dan Bio Diesel Untuk Penurunan Emisi Gas Buang Pada Kenderaan Bermotor", Tesis, Universitas Sumatera Utara, 2014.

[31] Stadelman, W.J., Debbie Newkirk, Lynne Newby, "Eggs and egg products", Journal, In: Francis, F.J. (Ed.), Encyclopedia of Food Science and Technology, Edisi ke 2, hal. 593-599, 2000.

[32] Yatim, M.J, "Pra Rancangan Pabrik Pembuatan Sabun Transparan dari Minyak Kelapa Sawit (RBDPO) dan VCO Dengan Kapasitas 120.000 Ton/Tahun", Tugas Akhir, Universitas Sumatera Utara, 2011. 